\title{
Basic Study of Chemical Constituents in Rhizophora Species
}

\author{
Nurul Auni Zainal Abidin", Nurul Huda Abdul Halim and Ropisah Me
}

Faculty of Applied Science, Universiti Teknologi MARA Negeri Sembilan, Kampus Kuala Pilah, Beting, 72000 Kuala Pilah, Negeri Sembilan, Malaysia

\begin{abstract}
Rhizophora apiculata and Rhizophora mucronata are the mangrove plants of the genus Rhizophora. The chemical constituents of leaf samples for both species were analyzed by using Gas Chromatography-Mass Spectrometry (GC-MS). The analysis of chemical constituents of Rhizophora apiculata was found to be rich in 2-(2ethoxyethoxy)ethanol (26.45\%) and Kaur-16-ene (3.37\%). Benzophenone (16.09\%) and 2-(2-ethoxyethoxy)ethanol $(7.82 \%)$ were the predominant constituents in Rhizophora mucronata.
\end{abstract}

Keywords: Mangrove, Rhizophora apiculata, Rhizophora mucronata, chemical constituents.

\section{INTRODUCTION}

Rhizophora species are medical plants of eastern and southeast Asia. Mangrove Rhizophora species which are the most common representatives are Rhizophora mucronata, Rhizophora mangle, and Rhizophora apiculata. Mangrove plants are a group of trees and shrubs growing along seashores in tropical and subtropical areas [1]. Extracts of mangrove plants were demonstrated to have biological activity against human animal and plant pathogens, such as human immunodeficiency virus [2]. Rhizophora apiculata blume is one of the major species of Rhizophora genus. The polysaccharide extracted from the leaf of Rhizophora apiculata was assessed in cell culture systems, for its activity against human immuno-deficiency viruses. The study indicated that a polysaccharide extracted from Rhizophora apiculata has anti-HIV activity in vitro, apparently due to interference with the adsorption of virus particles to positive human cells [3]. While, the various parts of Rhizophora mucronata find its use to treat human ailments like angina, dysentery, hematuria, and many more [4]. In Malaysia, Rhizophora apiculata and Rhizophora mucronata, or locally known as bakau minyak and bakau kurap, are the famous mangrove plant widely used in charcoal industry. It has been reported to produce high yields of tannins [5]. The present work therefore focuses on the Rhizophora apiculata and Rhizophora mucronata as the sample to be analyzed. The objectives of this research are i) to analyze the chemical constituents in leaf of Rhizophora mucronata and Rhizophora apiculata ii) to characterize and determine the chemical constituents from Rhizophora species using GC-MS.

\section{EXPERIMENTAL}

\subsection{Materials and Chemicals}

Methanol, ethyl acetate, and hexane were obtained from J. T. Baker (USA). Whatman No. 1 filter paper was

*Address correspondence to this author at the Faculty of Applied Science, Universiti Teknologi MARA Negeri Sembilan, Kampus Kuala Pilah, Beting, 72000 Kuala Pilah, Negeri Sembilan, Malaysia;

E-mail: nurulauni@ns.uitm.edu.my purchased from Sigma (Sigma Aldrich GmbH, Sternheim, Germany). While, double-distilled deionized water of at least $18 \mathrm{M} \Omega$ was purified by Nano ultra pure water system (Barnstead, USA).

\subsection{Instrumentation}

Gas chromatography-mass spectrometry (GC-MS) analyses were performed using a Hewlett-Packard (Palo Alto, CA, USA) gas chromatograph, and equipped with MSD Thermal Aux 2. A HP-Inno Wax capillary column, 30 $\mathrm{m}$ long, $0.25 \mathrm{~mm}$ internal diameter, and $0.25 \mu \mathrm{m}$ thickness was used. The column initial temperature was programmed at $50^{\circ} \mathrm{C}(3 \mathrm{~min})$ with an increase of $6^{\circ} \mathrm{C} / \mathrm{min}$ up to $250^{\circ} \mathrm{C}(5$ $\mathrm{min})$. Helium was used as the carrier gas. The temperature for injector and detector were $250^{\circ} \mathrm{C}$. An injection volume of $1.0 \mu 1$ was used.

\subsection{Plant Materials}

Leaf samples of Rhizophora mucronata and Rhizophora apiculata were collected from from swamp forest Port Dickson, Negeri Sembilan, Malaysia.

\subsection{Component Identification}

Components were identified by matching their mass spectra with those recorded in the NIST mass spectral library.

\section{RESULTS AND DISCUSSION}

The chemical constituents of the leaf oils of Rhizophora apiculata and Rhizophora mucronata are listed in Table $\mathbf{1}$ and Table 2. All the fresh samples gave pale yellow oils in the range of $0.02-0.18 \%$. The analysis of the oils successfully identified five components $(37.31 \%)$ in Rhizophora apiculata, and five components $(29.90 \%)$ in Rhizophora mucronata, respectively.

From the analysis of the two Rhizophora species, 2-(2ethoxyethoxy)ethanol were presented in both species ( $26.45 \%$ and $7.82 \%$, respectively). The analysis of chemical constituents of Rhizophora apiculata was found to be rich in 2-(2-ethoxyethoxy)ethanol (26.45\%) and Kaur-16-ene 
Table 1. Chemical Constituents of Leaf of Rhizophora Apiculata.

\begin{tabular}{|c|c|c|c|c|}
\hline No. & $\mathbf{t}_{\mathbf{R}}(\mathbf{m i n})$ & Constituents & Percentage (\%) & Probability (\%) \\
\hline \hline 1 & 15.64 & 2-(2-ethoxyethoxy)ethanol & 26.45 & 72 \\
\hline 2 & 17.13 & Hexadecamethyl cyclooctasiloxane & 2.67 & 83 \\
\hline 3 & 24.95 & 3,4 diethylphenol & 3.61 & 83 \\
\hline 4 & 27.93 & Kaur $-16-$ ene & 3.37 & 93 \\
\hline 5 & 29.46 & benzophenone & 3.21 & \\
\hline
\end{tabular}

Table 2. Chemical Constituents of Leaf of Rhizophora Mucronata

\begin{tabular}{|c|c|c|c|c|}
\hline No. & $\mathbf{t}_{\mathbf{R}}(\mathbf{m i n})$ & Constituents & Percentage (\%) & Probability (\%) \\
\hline \hline 1 & 15.63 & 2-(2-ethoxyethoxy)ethanol & 7.82 & 93 \\
\hline 2 & 20.92 & butylated hydroxytoluene & 2.29 & 84 \\
\hline 3 & 22.67 & icosamethylcyclodecasiloxane & 0.56 & 93 \\
\hline 4 & 25.61 & $2,3,4,5$-tetramethoxytoluene & 3.14 & 97 \\
\hline 5 & 29.46 & benzophenone & 29.90 & \\
\hline
\end{tabular}

(3.37\%). Benzophenone (16.09\%) and 2-(2-ethoxyethoxy) ethanol $(7.82 \%)$ were the predominant constituents in Rhizophora mucronata.

\section{CONCLUSION}

The analysis of chemical constituents of Rhizophora apiculata was found to be rich in 2-(2-ethoxyethoxy)ethanol $(26.45 \%)$ and Kaur-16-ene (3.37\%). Benzophenone (16.09\%) and 2-(2-ethoxyethoxy)ethanol (7.82\%) were the predominant constituents in Rhizophora mucronata. As the results, these findings can give additional information about Rhizophora species and can be used to distinguish between both species.

\section{CONFLICT OF INTEREST}

The authors confirm that this article content has no conflicts of interest.

\section{ACKNOWLEDGEMENTS}

The authors would like to thank Research Management Institute (RMI), Universiti Teknologi MARA for financial support through the Excellence Fund and Chemistry Laboratory, Universiti Teknologi Mara Negeri Sembilan.

\section{REFERENCES}

[1] Tomlinson, P.B. The Botany of Mangroves. Cambridge University Press: Cambridge, 1994

[2] Basyuni, M.; Oku, H.; Tsujimoto, E.; Kinjo, K.; Baba, S.: Takara, $\mathrm{K}$. Triterpene synthases from the Okinawan mangrove tribe, Rhizophoraceae. FEBS J., 2007, 274(19), 5028-5047.

[3] Premanathan, M,; Arakaki, R,; Izumi, H,; Kathiresan, K,; Nakano, M,; Yamamoto, N,; Nakashima, H. Antiviral properties of a mangrove plant, Rhizophora apiculata Blume, against human immunodeficiency virus. Antiviral Res., 1999, 44, 113-122.

[4] Joel, E.L.; Bhimba, V. Isolation and characterization of secondary metabolites from the mangrove plant Rhizophora mucronata. Asian Pac. J. Trop. Med., 2010, 3(8), 602-604.

[5] Jain, K.; Afidah, A.R.; Azman, I.M. Proceedings of the Symposium of Malaysian Chemical Engineering, Malaysia 2002, pp. 323-327. 